\title{
Study of the Nutritional Characteristics and Technological Properties of Xanthosoma sagittifolium Tubers (Tabouchi) from Burkina Faso
}

\section{Kaboré Donatien $^{1} *$, Ouattara Cheik Amadou Tidiane ${ }^{2}$, Paré Adama ${ }^{1}$, Samadoulougou- Kafando Pingdwindé Marie Judith ${ }^{1}$ and Traoré Sabedenedjo Alfred ${ }^{2}$}

${ }^{1}$ Département Technologie Alimentaire, IRSAT/CNRST, 03 BP 7047 Ouagadougou 03, Burkina Faso

${ }^{2}$ Centre de Recherche en Sciences Biologiques, Alimentaires et Nutritionnelles (CRSBAN), UFR/SVT, Université Ouaga I Professeur Joseph KI-ZERBO, Ouagadougou, Burkina Faso. 03

BP 7021 Ouaga 03

*Corresponding author

\section{A B S T R A C T}

\begin{tabular}{|l|}
\hline Keyw or d s \\
Tabouchi flour, \\
proximate and \\
mineral \\
composition, \\
gelatinization, \\
pasting profiles.
\end{tabular}

\begin{abstract}
In the present study, flour from tabouchi or Xanthosoma sagitifolium tuber was analyzed for biochemical composition, physico-chemical, gelatinization and pasting property. It appears that the tuber is nutritious and the results showed that tabouchi is essentially a carbohydrate food ( $83 \%$ dry weight $(\mathrm{dw})$ ). Furthermore tabouchi contains protein, fat, ash, fiber and vitamin $\mathrm{C}$ to the respective mean contents of 7.61, 0.99, 4.21, 3.76, and 0.013 $\mathrm{g} / 100 \mathrm{~g} \mathrm{dw}$. Our study showed that $100 \mathrm{~g}(\mathrm{dw})$ of tabouchi flour contains $217.88 \mathrm{mg}$ of phosphorous (P), $109.15 \mathrm{mg}$ of Calcium $(\mathrm{Ca}), 45.79 \mathrm{mg}$ of sodium $(\mathrm{Na}), 2208 \mathrm{mg}$ of potassium $(\mathrm{K})$ and $3.43 \mathrm{mg}$ of iron $(\mathrm{Fe})$. The second part of our study focused on the physicochemical properties of the flour from tabouchi. Water absorption capacity, Oil absorption capacity and Solubility of tabouchi flour were $2.10 \mathrm{~mL} / \mathrm{g} \mathrm{dw}, 0.85 \mathrm{~mL} / \mathrm{g} \mathrm{dw}$ and $89 \mathrm{mg} / 100 \mathrm{~g} \mathrm{dw}$ respectively. Swelling of tabouchi flour increased with temperature. Pasting temperature $\left(79^{\circ} \mathrm{C}\right)$, Peak viscosity $(66.70 \mathrm{cP})$ and setback $(40 \mathrm{cP})$ obtained during the study of the gelatinization and the pasting profiles suggested that tabouchi flour could be subject to its possible use in food technology. Interestingly, tabouchi could help reducing proteino-energetic malnutrition and some micronutrient deficiencies in our country.
\end{abstract}

\section{Introduction}

Xanthosoma sagittifolium tuber is an important source of carbohydrate in Tropical Africa including Burkina Faso. The tubers can also be processed in several ways to produce food and feed products. Among the processes, the tubers can be subjected to boiling, roasting, frying, milling and conversion to soup thickeners, flour for baking, chips, beverage powder, porridge, and speciality food for gastro- intestinal disorders (Onwueme, 1978). In Burkina Faso where diet is characterized by a predominance of grain, the corms of $X$. sagittifolium are usually eaten boiled.

Several studies evaluated the chemical composition of $X$. sagittifolium tubers in Cameroon (Agbor-Egbe and Rickard, 1990), 
in Ivory Coast (Amani et al., 1993), in Nigeria (Yahaya et al., 2013), in Ghana (SefaDedeh and Agyir-Sackey, 2004), in Venezuela (Perez et al., 2007), showing thattubers from $X$. sagittifolium contain digestible starch, protein of good quality, vitamin $\mathrm{C}$, thiamin, riboflavin, niacin and high scores of amino acids.

However, the tubers have a short shelf life because of their high moisture content which can lead to damage during harvest and storage. One of the best ways to preserve them may be by processing them to obtain flour and/or starches. Flour obtained from theses tubers have never been commercialized in Burkina Faso because their properties are unknown.

In order to collect data that could help to promote tabouchi in our country, we began determining its biochemical composition and the study of its technological properties. The objective was to contribute to the fight against hunger and malnutrition on the one hand, and improving tabouchi processing technology in Burkina Faso.

\section{Materials and Methods}

\section{Materials}

Fresh tuberous roots of Xanthosoma sagittifolium were harvested in N'Dorola located in South -West region of Burkina Faso. The samples were transported to the laboratory where they were selected, washed with water, peeled and cut into small slices with a knife to promote drying in an oven at $60{ }^{\circ} \mathrm{C}$. The dried fragments were then ground using a mortar. The flour obtained after sieving through at $0.5 \mathrm{~mm}$ mesh sieve was collected in a polyethylene bag and stored in the refrigerator for different analyzes. Analyzes were performed in triplicate.

\section{Chemical composition}

Standard Association of Official Analytical Chemistry (AOAC) methods (1996) were adopted for estimating moisture, ash, crude fibre, protein and fat contents. Total carbohydrates were determined by using the orcinol (3, 5-dihydroxytoluène)/sulfuric and the absorbance was measured at $510 \mathrm{~nm}$ according to the method of Tollier and Robin (1979). Starch content was determined using the spectrometric method described by Jarvis and Walker (1993).

\section{Determination of mineral composition}

Phosphorus was determined by a colorimetric method described by Stuffins (1967). $1 \mathrm{~g}$ of flour was digested with a mixture of $\mathrm{HClO}_{4}$ $70 \%$, HNO3 $65 \%$ and $\mathrm{H} 2 \mathrm{SO} 498 \%$ in a kjedahl digestion tube. Digestion was initially at low heat until the brown fumes had escaped and heating continued until the appearance of white fumes emerge. After cooling, the digest is transferred into $100 \mathrm{~mL}$ volumetric flask and made up to the mark with distilled water.

$1 \mathrm{~mL}$ of the digested solution was mixed with $5 \mathrm{~mL} \mathrm{H} 2 \mathrm{O}$ and $4 \mathrm{~mL}$ of mixture composed of $\mathrm{H}_{2} \mathrm{SO}_{4} 0.1 \mathrm{~N}$, molybdic ammonium $1 \%$ and ascorbic acid $1 \%$. The mixture was vortexed and allowed to stand for $30 \mathrm{~min}$ and absorbance at $820 \mathrm{~nm}$ was read against blank solution which was prepared as appropriate.

Two (2) $\mathrm{mL}$ of the digested solution were used to determine $\mathrm{Na}$ and $\mathrm{K}$ contents using a Flame Photometer (model 410) and absorbance at $589 \mathrm{~nm}(\mathrm{Na})$ and $768 \mathrm{~nm}(\mathrm{~K})$ were read.

The method using Ethylene Diamine Tetraacetic Acid (EDTA) was applied to determine $\mathrm{Ca}$ content in $5 \mathrm{~mL}$ of the digested solution (Bouguerra, 1988). 
Fe content was determined using the method described by Bandemer and Schaible (1944).

Physico-chemical property of flour from $X$. sagittifolium

\section{Determination of water absorption capacity}

Water absorption capacity was determined using methods described by Beuchat (1977). 1 $\mathrm{g}$ of sample was weighed into $25 \mathrm{~mL}$ graduated conical centrifuge tubes; both weight noted, then $10 \mathrm{~mL}$ of water added. The suspensions were allowed to stand at room temperature $\left(30^{\circ} \mathrm{C}\right)$ for $1 \mathrm{~h}$. The suspension was centrifuged at $6000 \mathrm{rpm}$ for $20 \mathrm{~min}$. The supernatant was decanted and then the sample was reweighed. The change in weight was expressed as percent water absorption based on the original sample weight. Analysis was conducted in triplicate.

\section{Determination of oil absorption capacity}

The method described by Beuchat (1977), was adopted in determining the oil absorption capacity. $1 \mathrm{~g}$ of sample was weighed into a dry, clean centrifuge tube and both weight noted. Peanut oil $(10 \mathrm{~mL})$ with density of $0.85 \mathrm{~g} / \mathrm{ml}$ was poured into the tube and properly mixed with the samples using a stainless steel spatula; the suspension was centrifuged at $6000 \mathrm{rpm}$ for $20 \mathrm{~min}$, then, the supernatant was discarded and the tube with its content reweighed. The gain in mass expressed as a percentage of oil bound is the oil absorption capacity of the sample. Analysis was conducted in triplicate.

\section{Swelling power determination of the flour}

The method described by Subramanian et al (1986) was adopted to determine swelling power of flour from tabouchi. $0.5 \mathrm{~g}$ of flour were dispersed in $5 \mathrm{~mL}$ of distilled water in a pre-weighed centrifuge tubes. The slurries were heated in a thermostatically controlled water bath at $95^{\circ} \mathrm{C}$ for $60 \mathrm{~min}$ with constant stirring. The same experiment was carried out at $70,75,80,85$ and $90^{\circ} \mathrm{C}$. The heated slurries were then cooled to room temperature and centrifuged at $5000 \mathrm{rpm}$ for $10 \mathrm{~min}$ to separate gel and supernatant. The supernatant was decanted carefully and poured into dish. Weight of swollen flour was determined and swelling power was determined as the ratio of the weight of the swollen flour to the weight of the initial flour sample.

\section{Solubility determination of the flour}

The method described by Subramanian et al (1986) was adopted to determine solubility of flour from tabouchi. $0.5 \mathrm{~g}$ of flour were dispersed in $15 \mathrm{~mL}$ of distilled water in a preweighed centrifuge tubes. The slurries were heated in a thermostatically controlled water bath at $90^{\circ} \mathrm{C}$ for $60 \mathrm{~min}$ with constant stirring. The heated slurries were then cooled to room temperature and centrifuged at $7000 \mathrm{rpm}$ for 15 min to separate gel and supernatant. The supernatant was decanted carefully and poured into a weighed evaporating dish and dried at $110^{\circ} \mathrm{C}$ for $20 \mathrm{~min}$. The difference in weight of the evaporating dish was used to calculate flour solubility.

\section{Determination of pasting properties}

Pasting properties of flour from $X$. sagittifolium tubers were determined in duplicate using a Brookfield viscosimeter (HBDVII, version 2, model LVT, USA) according to the method described by Faladé and Okafor (2013).A suspension of $10 \mathrm{~g}$ of tabouchi flourin $100 \mathrm{~mL}$ distilled water was heated from $37^{\circ} \mathrm{C}$ to $95^{\circ} \mathrm{Cwith}$ constant stirring. The sample was held at $95^{\circ} \mathrm{C}$ for 15 min (breakdown) and then cooled to $50^{\circ} \mathrm{C}$ (setback). Pasting curve was obtained for the flour. Viscoamylograph profiles were 
determined as follows: the pasting temperature was defined as the temperature at which an increase in viscosity was first detected by the instrument; peak viscosity was defined as the equilibrium point between swelling and polymer leaching; trough was defined as the lowest viscosity; final viscosity was defined as the viscosity of the sample at the end of the cycle period; setback was defined as the difference between final viscosity and peak viscosity; peak time was defined as the time the peak viscosity occurred.

\section{Statistical analysis}

The parameters evaluated in the present study were assessed in triplicate $(n=3)$ and reported as average \pm standard deviation.

\section{Results and Discussion}

Proximate composition of flour from Tabouchi (X. sagittifolium) tubers

Table.1 presents the proximate composition of tabouchi flour.

Moisture content obtained $(72.91 \%$ on fresh weight basis) was lower than those reported by Onwueme in 1978 (77.50\% dw) but higher than those reported by Perez et al. in 2007 (67.01\% dw) and Agbor-Egbe and Rickard in 1990. (68.40\% dw). Moisture content is a quality factor for preservation, convenience in packaging and transport.

Fiber content from Tabouchi flour $3.76 \%$ $\mathrm{dw}$ ) was lower than those obtained byPerez et al (2007) but higher than the value of Onwueme (1978).

Starch is a major component of plant foods and an important raw material for industry. Our study showed that the starch content in tabouchi is $68.66 \% \mathrm{dw}$, that is similar to the value obtained by Perez et al (2007) but lower than those reported Agbor-Egbe and Rickard (1990).

Total carbohydrates content from tabouchi flour is $82.63 \% \mathrm{dw}$. Similar results were obtained by Treche and Guion (1980) and Onwueme (1978).

Concerning the protein content, tabouchi contains $7.61 \% \mathrm{dw}$. Onwueme (1978) showed high value $11.11 \% \mathrm{dw}$ ) whereas low value $(6.37 \% \mathrm{dw})$ was found by Perez et al. (2007).

The ash content from Tabouchi $(4.21 \mathrm{dw})$ was lower than those reported $5.50 \%$, by Abdulrashid and Agwunobi in 2012 (5.50\% $\mathrm{dw}$ ) but our value was higher than those found by Onwueme (1978). Perez et al. (2007) found similar ash content $(4.25 \% \mathrm{dw})$. Ash content could be explained by botanical source, different seasons and soil conditions.

Tabouchi was found to contain $0.99 \% \mathrm{dw}$ of fat that is higher than the value $(0.88 \% \mathrm{dw})$ reported by Perez et al. (2007) and Onwueme (1978). But the fat content was lower than those reported by Abdulrashid and Agwunobi in $2012(1.50 \% \mathrm{dw})$.

The mineral content of tubers from $X$. sagittifolium was investigated. Our study showed that $100 \mathrm{~g}(\mathrm{dw})$ of Tabouchi flour contains $217.88 \mathrm{mg}$ of phosphorous (P), $109.15 \mathrm{mg}$ of Calcium (Ca), $45.79 \mathrm{mg}$ of sodium $(\mathrm{Na}), 2208 \mathrm{mg}$ of potassium $(\mathrm{K})$ and $3.43 \mathrm{mg}$ of iron $(\mathrm{Fe}) . \mathrm{P}, \mathrm{K}$ and $\mathrm{Na}$ contents were lower than those reported by AgborEgbe and Rickard (1990). The content of Fe in tabouchi flour was similar to those found by Onwueme (1978) but high than those reported by Agbor-Egbe and Rickard (1990).

The mineral content is dependent on the botanical source and soil conditions. 


\section{Physico-chemical property of Tabouchi flour}

The Water absorption capacity $(2.10 \mathrm{~mL} / \mathrm{g}$ $\mathrm{dw})$ was 2.5 times higher than the Oil absorption capacity $(0.85 \mathrm{~mL} / \mathrm{g} \mathrm{dw})$. This result lends credence to observations of Iwuoha and Kalu (1994).The water absorption found in our study is lower than the value obtained by Perez et al, in $2007(2.84 \mathrm{~mL} / \mathrm{g}$ $\mathrm{dw}$ ). Our sample showed higher oil absorption capacity when compared to the flour samples described by Faladé and Okafor (2013) ranging from $25.0 \%$ to $33.5 \%$. Oil absorption capacity reflects the emulsifying capacity, a highly desirable characteristic in products such as mayonnaise, denoting the amount of oil that can be picked up by a sample during processing, for instances how samples will react during frying (Faladé and Okafor, 2013).

Solubility of tabouchi flour was $89 \mathrm{mg} / 100 \mathrm{~g}$ $\mathrm{dw}$. This value was higher than those found by Subramanian et al. (1986) for pearl millet flour. This result suggests that tabouchi flour could be used to produce zoom-kom, a local juice from Burkina Faso made from millet grains.
Fig.1 shows the effect of temperature on flour swelling capacity. The flours swelling capacity increased from 3 to 8 between $70^{\circ} \mathrm{c}-$ $85^{\circ} \mathrm{c}$ but decreased to about 6.8 at $95^{\circ} \mathrm{C}$. This property is similar to those observe by Amani et al. (1993) and Rasper (1969). However it was found that oxidation and acid-thinning reduced the swelling power (Lawal , 2004).

\section{Viscosity}

Fig. 2shows the viscosity of Xanthosoma sagittifolium flour as a function of temperatures. This figure is similar to that obtained by Rasper (1969).

Indeed, it was first detected an increase in viscosity at $79^{\circ} \mathrm{C}$ (pasting temperature) corresponding to the gelatinization of the starch. Four (04) min later (Peak time), the value of the viscosity was maximum corresponding to $66.70 \mathrm{cP}$ (Peak viscosity). During the constant temperature $(15 \mathrm{~min}$ at $\left.95^{\circ} \mathrm{C}\right)$, the viscosity breakdown to 53.3 $\mathrm{cP}$ (Trough) corresponding to a loss of $13.7 \mathrm{cP}$ $(20.08 \%)$.

Table.1 Proximate composition of tabouchi flour

\begin{tabular}{|l|l|}
\hline Component & Values \\
\hline Moisture (\% fresh weight basis) & $72,91 \pm 2.04$ \\
\hline Fat $(\% \mathrm{dw})$ & $0,99 \pm 0.1$ \\
\hline Crude Protein $(\% \mathrm{dw})$ & $7,61 \pm 0.11$ \\
\hline Totalcarbohydrates $(\% \mathrm{dw})$ & $82,63 \pm 1.6$ \\
\hline Starch $(\% \mathrm{dw})$ & $68,66 \pm 2.03$ \\
\hline CrudeFiber $(\% \mathrm{dw})$ & $3,76 \pm 0.44$ \\
\hline Ash $(\% \mathrm{dw})$ & $4,21 \pm 0.4$ \\
\hline $\mathrm{P}(\mathrm{mg} / 100 \mathrm{~g})$ & $217,88 \pm 5.6$ \\
\hline $\mathrm{Ca}(\mathrm{mg} / 100 \mathrm{~g} \mathrm{dw})$ & $109,15 \pm 3.4$ \\
\hline $\mathrm{K}(\mathrm{mg} / 100 \mathrm{~g} \mathrm{dw})$ & $2208 \pm 8.3$ \\
\hline $\mathrm{Na}(\mathrm{mg} / 100 \mathrm{~g} \mathrm{dw})$ & $45,79 \pm 4.42$ \\
\hline $\mathrm{Fe}(\mathrm{mg} / 100 \mathrm{~g} \mathrm{dw})$ & $3,43 \pm 3.43$ \\
\hline
\end{tabular}

Values are Mean \pm SD of triplicate determination 
Table.2 Gelatinization and pasting profile of Tabouchi flour

\begin{tabular}{|l|l|}
\hline Profiles & Values \\
\hline Pasting temperature (Initial gelatinization temperature) & $79^{\circ} \mathrm{C}$ \\
\hline Peak viscosity & $66,70 \mathrm{cP}$ \\
\hline Peak time & $4 \mathrm{~min}$ \\
\hline Trough (Breakdown) (A) & $53.3 \mathrm{cP}$ \\
\hline Final viscosity (B) & $106.7 \mathrm{cP}$ \\
\hline Setback: B-A & 53.4 \\
\hline
\end{tabular}

Fig.1 Effect of temperature on flour swelling capacity

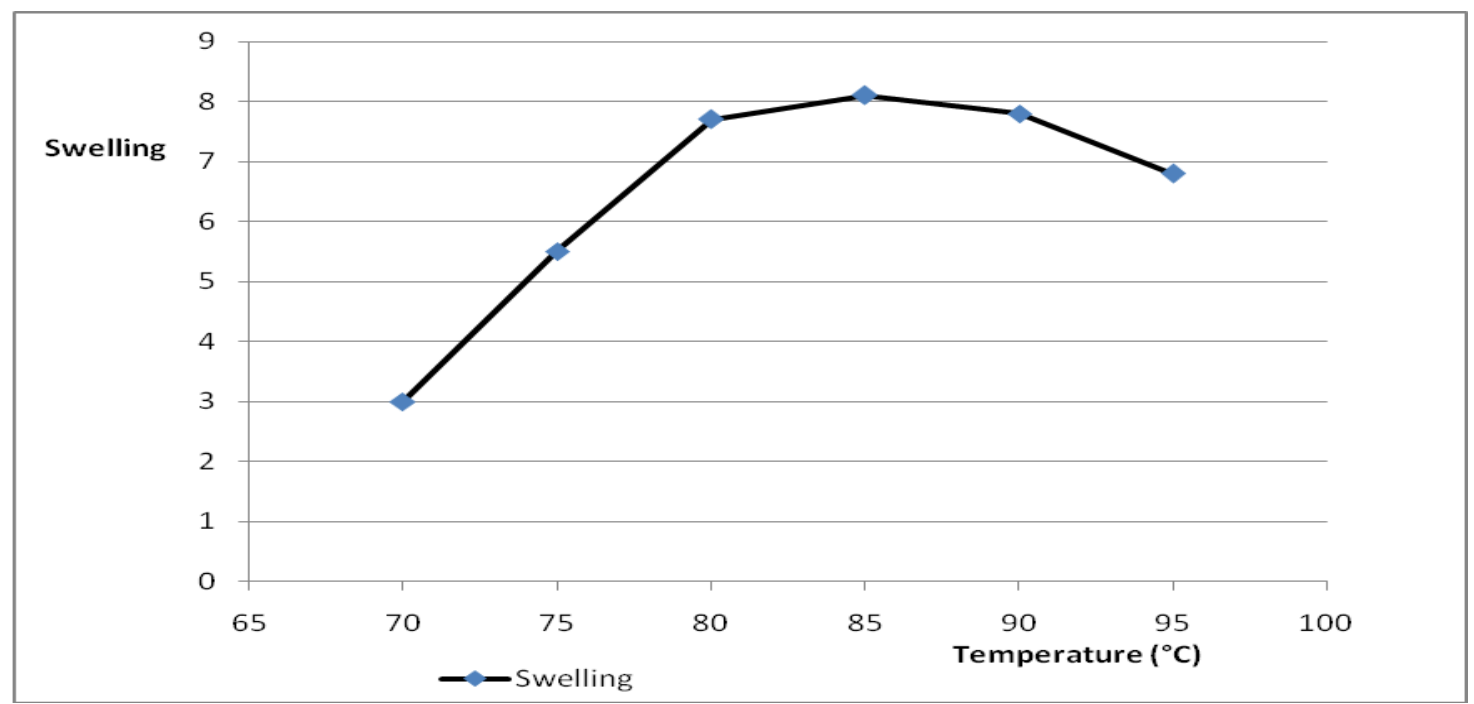

Fig.2 Viscosity of Xanthosoma sagittifolium flour

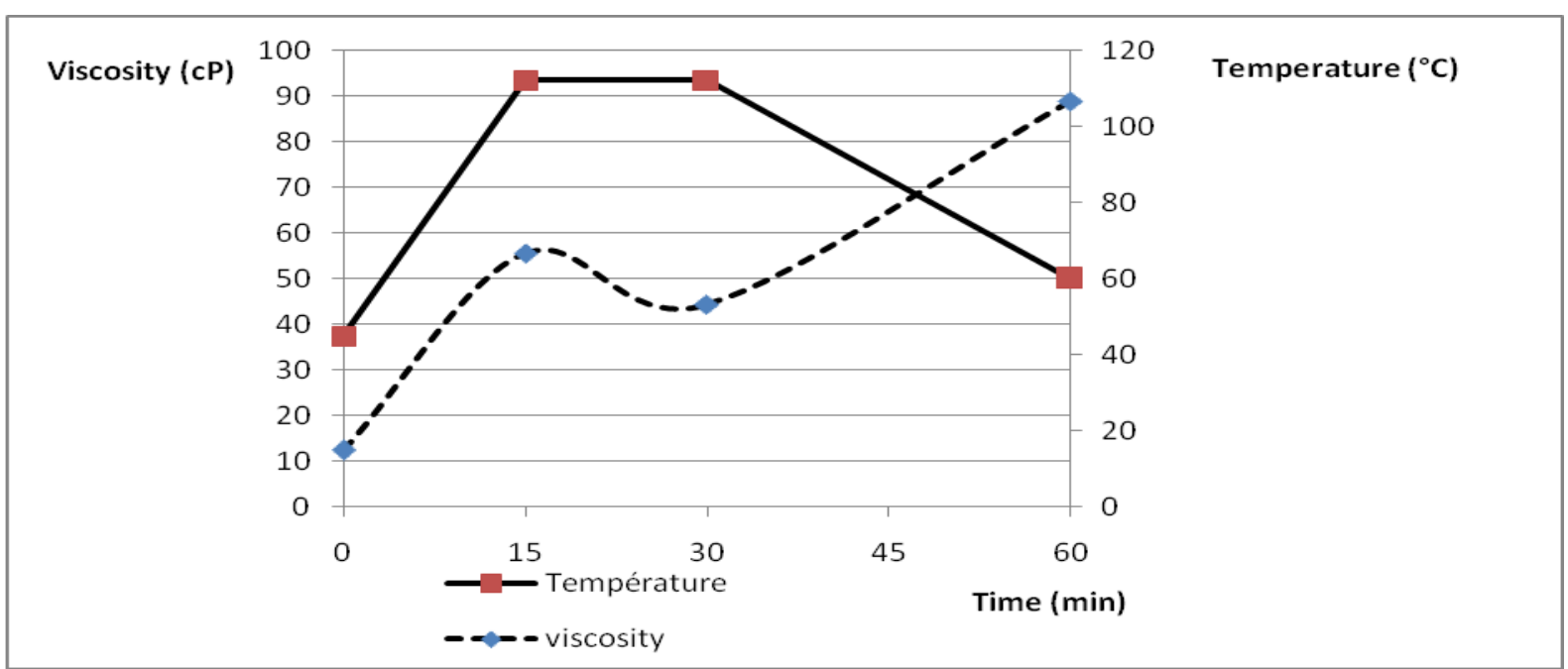


During cooling, the viscosity increased to $106.7 \mathrm{cP}$ (final viscosity) and the setback was estimated to 53.4.Table2 summarizes the gelatinization and the pasting profiles of Tabouchi flour. Pasting temperature influence the ability of flour to imbibe water and swell. The pasting temperature found in the present study does not correspond with range of $84.53-88.75^{\circ} \mathrm{C}$ for Colocasiaes culenta and Xanthosoma sagittifolium (Falade and Okafor, 2013). But our pasting temperature is close to that obtained by Lawal in $2004\left(76^{\circ} \mathrm{C}\right)$.

The peak viscosity, the breakdown as well as the final viscosity of tabouchi flour were lower than those obtained by Lu et al. (2005). This is interesting because it is well known that Flour with a lower peak viscosity has a lower thickening power than flour with a higher peak viscosity. Setback, defined as the difference between the breakdown viscosity and the viscosity at $50^{\circ} \mathrm{C}$ and determining the tendency of starch to retrogradation, was found to be lower than the value reported by Lu et al. (2005). The peak time found in the present study is lower than those observed by Falade and Okafor (2013) who reported peak time of the cocoyam starches ranging from $4.55 \mathrm{~min}$ to $4.97 \mathrm{~min}$. The authors expected these results as high peak times characterize low swelling starch granules in the flour.

In conclusion, our study suggested that the flour from tabouchi could be considered of potential nutritional quality and good physicochemical property and may contribute to new product development by local food industries. The information provided by flour gelatinization profiles illustrates that Tabouchi may be useful for the use of its flour as ingredients in food formulation and processing. Wheat flours are usually suggested for bread making and also for the manufacture of baked goods, snack, pasta, and noodles. Tabouchi flour could be proposed if wheat flour use is to be reduced.
In such a case, it might be interesting that the amylose content be quantified for food processing and quality.

\section{Acknowledgements}

Meaningful contribution of Prof. TraoréSabedenedjo Alfred is appreciated. The author also wishes to thank the farmers from N'Dorola where the tubers of $X$. sagittifolium were collected. The authors are indebted to University Ouaga I Prof. Joseph Ki-Zerbo for financial support and providing the laboratory for experiments.

\section{References}

Abdulrashid, M. and Agwunobi, L.N. 2012. Tannia (Xanthosoma sagittifolium) Cocoyam as Dietary Substitute for Maize in Broiler Chicken. Greener J. Agric. Sci., 2 (5): 167-171.

Agbor-Egbe, T. and Rickard, E. J. 1990. Evaluation of the chemical composition of fresh and stored edible aroids. J. Sci. Food Agric., 53:487 - 495.

Amani, N.G., Aboua, F., Gnakri, D., Kamena, A. 1993. Etudes des propriétés physicochimiques de l'amidon de taro (Xanthosoma sagittifolium). Cahier scientifique, 110:136-142.

AOAC (Association of Official Analytical Chemists), 1996.Official methods of analysis, Washingtown, DC, USA.

Bandemer, S.L. and Schaible, P.J. 1944. Determination of iron.A study of the Ophenanthroline method. Ind. Eng. Chem. Anal., 16: 317-319.

Beuchat, L.R. 1977. Functional and electrophoretic characteristics of succinylated peanut flour protein. $J$. Agric. Food Chem., 25: 258-261.

Bouguerra, M.L. 1998. Chimie et developpement. $2^{\text {nde }}$ ed., Masson, 308 p.

Falade, K.O., Okafor, C.A. 2013.Physicochemical properties of five cocoyam (Colocasiaes culenta and 
Xanthosoma sagittifolium) starches. Food Hydrocolloids, 30:173-181.

Iwuoha, I.C. and Kalu, A.F. 1994. Calcium oxalate and physico-chemical properties of cocoyam (Colocasiaesculenta and Xanthosoma sagittifolium ) tuber flours as affected by processing. Food Chem., 54: 61-66.

Jarvis, E.C. and Walker, R.L. 1993. Simultaneous, rapide, spectrometric determination of total starch, amylose and amylopectin. J. Sci. Food Agric., 63:53-57.

Lawal, O.S. 2004. Composition, physicochemical properties and retrogradation characteristics of native, oxidised, acetylated and acid-thinned new cocoyam (Xanthosoma sagittifolium) starch. Food Chem., 87: 205-218.

Lu, T.J., Chen, J.C., Lin, C.L. and Chang, Y.H. 2005. Properties of starches from cocoyam (Xanthosoma sagittifolium) tubers planted in different seasons. Food Chem., 91: 69-77.

Onwueme, C. I.1978. Colocasia and Xanthosoma. In the tropical Tuber Crops, John wiley \& Sons éd., Chichester, New York, USA, 199 - 227.

Perez, E.E., Gutierrez, M.E., Delahaye, E.P., Tovar, J. and Lares, M. 2007. Production and characterization of Xanthosoma sagittifolium and Colocasiaesculentaflours. J. food Sci., 72(6): 367- 372.
Rasper, V. 1969. Investigation on starches from major starch crop grown in Ghana. II. Swelling and solubility patterns and amyloelastic susceptibility. J. Sci. Food Agric., 20: 642-646.

Sefa-Dedeh, S. and Agyir-Sackey, E.K. 2004. Chemical composition and effect of processing on oxalate content of cocoyam Xanthosoma sagittifolium and Colocasiaesculenta cormels. Food chemistry 85(4): 479-487.

Stuffins, C.B. 1967. The determination of phosphate and calcium in feed stuffs. Analysis, 62:107-111.

Subramanian, V., Jambunathan, R. and Ramaiah, C.D. 1986. Physical and chemical characteristics of pearl millet grains and their relationship to roti quality. J. Food Sci., 51(4):1005-1009.

Tollier, M., Robin, J.P. 1979. Adaptation de la méthode à l'orcinol sulfurique au dosage automatique des glucides neutres totaux :conditions d'application aux extraits d'origine végétale. Ann. Technol. Agric., 28: 1-15.

Treche, S., Guion, P. 1980. Etude des potentialités nutritionnelles de quelques tubercules tropicaux au Cameroun. Revue Sci. Techn., 1: 71-80.

Yahaya, I.A., Nok, A.J. and Bonire, J.J. 2013. Chemical Studies of the peel of Xanthosoma sagittifolium (Tannia Cocoyam). Pakistan J. Nutr., 12(1): 4044.

\section{How to cite this article:}

Kaboré Donatien, Ouattara Cheik Amadou Tidiane, Paré Adama, Samadoulougou-Kafando Pingdwindé Marie Judith and Traoré Sabedenedjo Alfred. 2017. Study of the Nutritional Characteristics and Technological Properties of Xanthosoma sagittifolium Tubers (Tabouchi) from Burkina Faso. Int.J.Curr.Microbiol.App.Sci. 6(1): 379-386. doi: http://dx.doi.org/10.20546/ijcmas.2017.601.046 